ҚАЗАҚСТАН РЕСПУБЛИКАСЫ

ҰЛТТЫҚ ҒЫЛЫМ АКАДЕМИЯСЫНЫН

БАЯНДАМАЛАРЫ

ДОКЛАДЫ

НАЦИОНАЛЬНОЙ АКАДЕМИИ НАУК

РЕСПУБЛИКИ КАЗАХСТАН

\title{
REPORTS
}

OF THE NATIONAL ACADEMY OF SCIENCES

OF THE REPUBLIC OF KAZAKHSTAN

PUBLISHED SINCE 1944

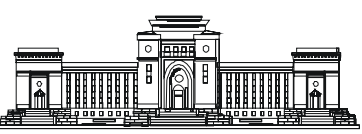




\author{
Ба с редак т о ры \\ х.ғ.д., проф., ҚР ҰҒА академигі \\ М.Ж. Жұрынов
}

Р едакция алқа сы:

\begin{abstract}
Адекенов С.М. проф., академик (Қазақстан) (бас ред. орынбасары)
Величкин В.И. проф., корр.-мүшесі (Ресей)

Вольдемар Вуйцик проф. (Польша)

Гончарук В.В. проф., академик (Украина)

Гордиенко А.И. проф., академик (Белорус)

Дука Г. проф., академик (Молдова)

Илолов М.И. проф., академик (Тәжікстан)

Кригер Виктор проф. (Германия)

Леска Богуслава проф. (Польша)

Локшин В.Н. проф., чЛ.-корр. (Қазақстан)

Нараев В.Н. проф. (Ресей)

Неклюдов И.М. проф., академик (Украина)

Нур Изура Удзир проф. (Малайзия)

Перни Стефано проф. (Ұлыбритания)

Потапов В.А. проф. (Украина)

Прокопович Полина проф. (Ұлыбритания)

Омбаев А.М. проф., корр.-мүшесі (Қазақстан)

Өтелбаев М.О. проф., академик (Қазақстан)

Садыбеков М.А. проф., корр.-мүшесі (Қазақстан)

Сатаев М.И. проф., корр.-мүшесі (Қазақстан)

Северский И.В. проф., академик (Қазақстан)

Сикорски Марек проф., (Польша)

Рамазанов Т.С. проф., академик (Қазақстан)

Такибаев Н.Ж. проф., академик (Қазақстан), бас ред. орынбасары

Харин С.Н. проф., академик (Қазақстан)

Чечин Л.М. проф., корр.-мүшесі (Қазақстан)

Харун Парлар проф. (Германия)

Энджун Гао проф. (Қытай)

Эркебаев А.Э. проф., академик (Қырғыстан)
\end{abstract}

«Қазақстан Республикасы Ұлттық ғылым академиясының баяндамалары»

ISSN 2518-1483 (Online),

ISSN 2224-5227 (Print)

Меншіктенуші: «Қазақстан Республикасының Ұлттық ғылым академиясы» Республикалық қоғамдық бірлестігі (Алматы қ.).

Қазақстан республикасының Мәдениет пен ақпарат министрлігінің Ақпарат және мұрағат комитетінде 01.06.2006 ж. берілген №5540-Ж мерзімдік басылым тіркеуіне қойылу туралы куәлік.

Мерзімділігі: жылына 6 рет.

Тиражы: 500 дана.

Редакцияның мекенжайы: 050010, Алматы қ., Шевченко көш., 28; 219, 220 бөл.; тел.: 272-13-19, 272-13-18, http://reports-science.kz/index.php/en/archive

(C) Қазақстан Республикасының Ұлттық ғылым академиясы, 2020

Типографияның мекенжайы: «NurNaz GRACE», Алматы қ., Рысқұлов көш., 103. 


\title{
Главны й редактор \\ д.х.н., проф., академик НАН РК \\ М. Ж. Журинов \\ Р едакци онная коллегия:
}

\author{
Адекенов С.М. проф., академик (Казахстан) (зам. гл. ред.) \\ Величкин В.И. проф., чл.-корр. (Россия) \\ Вольдемар Вуйцик проф. (Польша) \\ Гончарук В.В. проф., академик (Украина) \\ Гордиенко А.И. проф., академик (Беларусь) \\ Дука Г. проф., академик (Молдова) \\ Илолов М.И. проф., академик (Таджикистан) \\ Кригер Виктор проф. (Германия) \\ Леска Богуслава проф. (Польша) \\ Локшин В.Н. проф., чл.-корр. (Казахстан) \\ Нараев В.Н. проф. (Россия) \\ Неклюдов И.М. проф., академик (Украина) \\ Нур Изура Удзир проф. (Малайзия) \\ Перни Стефано проф. (Великобритания) \\ Потапов В.А. проф. (Украина) \\ Прокопович Полина проф. (Великобритания) \\ Омбаев А.М. проф., чл.-корр. (Казахстан) \\ Отелбаев М.О. проф., академик (Казахстан) \\ Садыбеков М.А. проф., чл.-корр. (Казахстан) \\ Сатаев М.И. проф., чл.-корр. (Казахстан) \\ Северский И.В. проф., академик (Казахстан) \\ Сикорски Марек проф., (Польша) \\ Рамазанов Т.С. проф., академик (Казахстан) \\ Такибаев Н.Ж. проф., академик (Казахстан), зам. гл. ред. \\ Харин С.Н. проф., академик (Казахстан) \\ Чечин Л.М. проф., чл.-корр. (Казахстан) \\ Харун Парлар проф. (Германия) \\ Энджун Гао проф. (Китай) \\ Эркебаев А.Э. проф., академик (Кыргызстан)
}

Доклады Национальной академии наук Республики Казахстан»

ISSN 2518-1483 (Online),

ISSN 2224-5227 (Print)

Собственник: Республиканское общественное объединение «Национальная академия наук Республики Казахстан» (г. Алматы).

Свидетельство о постановке на учет периодического печатного издания в Комитете информации и архивов Министерства культуры и информации Республики Казахстан №5540-Ж, выданное 01.06.2006 г.

Периодичность: 6 раз в год.

Тираж: 500 экземпляров

Адрес редакции: 050010, г.Алматы, ул.Шевченко, 28; ком. 219, 220; тел. 272-13-19, 272-13-18,

http://reports-science.kz/index.php/en/archive

(C) Национальная академия наук Республики Казахстан, 2020 г. 
Editorin chief

doctor of chemistry, professor, academician of NAS RK

M.Zh. Zhurinov

Editorial board:

Adekenov S.M. prof., academician (Kazakhstan) (deputy editor in chief)

Velichkin V.I. prof., corr. member (Russia)

Voitsik Valdemar prof. (Poland)

Goncharuk V.V. prof., academician (Ukraine)

Gordiyenko A.I. prof., academician (Belarus)

Duka G. prof., academician (Moldova)

Ilolov M.I. prof., academician (Tadjikistan)

Krieger Viktor prof. (Germany)

Leska Boguslava prof. (Poland)

Lokshin V.N. prof., corr. member (Kazakhstan)

Narayev V.N. prof. (Russia)

Nekludov I.M. prof., academician (Ukraine)

Nur Izura Udzir prof. (Malaysia)

Perni Stephano prof. (Great Britain)

Potapov V.A. prof. (Ukraine)

Prokopovich Polina prof. (Great Britain)

Ombayev A.M. prof., corr. member (Kazakhstan)

Otelbayv M.O. prof., academician (Kazakhstan)

Sadybekov M.A. prof., corr. member (Kazakhstan)

Satayev M.I. prof., corr. member (Kazakhstan)

Severskyi I.V. prof., academician (Kazakhstan)

Sikorski Marek prof., (Poland)

Ramazanov T.S. prof., academician (Kazakhstan)

Takibayev N.Zh. prof., academician (Kazakhstan), deputy editor in chief

Kharin S.N. prof., academician (Kazakhstan)

Chechin L.M. prof., corr. member (Kazakhstan)

Kharun Parlar prof. (Germany)

Endzhun Gao prof. (China)

Erkebayev A.Ye. prof., academician (Kyrgyzstan)

Reports of the National Academy of Sciences of the Republic of Kazakhstan.

ISSN 2224-5227

ISSN 2518-1483 (Online),

ISSN 2224-5227 (Print)

Owner: RPA "National Academy of Sciences of the Republic of Kazakhstan" (Almaty).

The certificate of registration of a periodic printed publication in the Committee of Information and Archives of the Ministry of Culture and Information of the Republic of Kazakhstan N 5540-Ж, issued 01.06.2006.

Periodicity: 6 times a year.

Circulation: 500 copies.

Editorial address: 28, Shevchenko str., of. 219, 220, Almaty, 050010, tel. 272-13-19, 272-13-18, http://reports-science.kz/index.php/en/archive

(C) National Academy of Sciences of the Republic of Kazakhstan, 2020

Address of printing house: «NurNaz GRACE», 103, Ryskulov str, Almaty. 


\title{
REPORTS OF THE NATIONAL ACADEMY OF SCIENCES OF THE REPUBLIC OF KAZAKHSTAN
}

ISSN 2224-5227

https://doi.org/10.32014/2020.2518-1483.27

Volume 2, Number 330 (2020), $21-28$

\author{
L. Chalova1, V. Lokshin ${ }^{2}$, M. Orazov ${ }^{3}$, A. Rybina ${ }^{2}$, T. Kim ${ }^{1}$, A. Kinzhibayev ${ }^{1}$ \\ ${ }^{1}$ LLP «M1» Health and Science Center LLP, Nur-Sultan, Kazakhstan; \\ ${ }^{2}$ ICCR «Persona», Almaty, Kazakhstan; \\ ${ }^{3}$ PFUR, Moscow, Russia. \\ E-mail: 1saat@mail.ru; v_lokshin@persona-ivf.kz; omekan@mail.ru; \\ kimtv_12@mail.ru; kinzhibay@gmail.com; oedema@mail.ru

\section{MODERN METHODS OF DIAGNOSIS AND TREATMENT OF CHRONIC ENDOMETRITIS, IN PREPARING PATIENTS FOR ASSISTED REPRODUCTIVE TREATMENT TECHNOLOGIES (LITERATURE REVIEW)}

\begin{abstract}
Since the chronic endometritis often leads to impaired reproductive function causing infertility, failed IVF attempts, miscarriage, and complicated pregnancy and childbirth, it has become not only medically relevant but also socially significant. For successful embryo implantation, the thickness of the endometrium should be at least $7 \mathrm{~cm}$. Even though there is always a chance for embryo implantation, despite the endometrial hypoplasia, the attachment may be fragile, and such pregnancy may cease its development further on. Recently, in connection with an increase in the rate of developing allergic reactions, dysbacteriosis, and the emergence of drug-resistant strains of microorganisms, a search for new treatment methods to avoid these complications has begun. One of such methods in treating chronic endometritis, satisfying several requirements (efficiency, comfort, accessibility, safety), is the ultrasonic cavitation of the uterine cavity.

Key words: ART, infertility, chronic endometritis, hypoplasia of endometrium, failed IVF attempts, ultrasonic cavitation.

Despite tremendous successes achieved in recent decades in the field of reproductive medicine, embryology, and genetics, the problem of infertile marriage is still far from being solved. According to world statistics, the effectiveness of Assisted Reproductive Technologies (ART) in overcoming infertility per transfer of one embryo does not exceed $25-40 \%$.

Infertility is the inability of a sexually active couple, who do not use contraception, to achieve pregnancy within one year. According to the World Health Organization (WHO), the infertility rate fluctuates between 15 and $18 \%$ and does not tend to decrease [1].

The beginning of the age of reproductive medicine has revealed new possibilities for preservation of fertility in both women and men. Today, the world uses such technologies as IVF, ICSI, epididymis and testis biopsy, gamete donation, surrogacy, preservation of fertility in cancer patients by cryopreservation of gametes - sperm and egg cells, cryopreservation of ovarian tissue for the future autotransplantion, preimplantation genetic testing of the embryo, and recently, experimental modification of human embryo genome $[2,3,4]$. Nevertheless, the development of new methods that can improve the effectiveness of ART is still ongoing.

In Kazakhstan, according to various sources, infertility rates reach $20 \%$. Thus, this has led to increased use of ART as the most effective way to overcome infertility, as well as the implementation of ART into the state program [4].

Disruption of proper implantation during the transfer of good quality embryos due to non-receptive endometrium is the most significant cause of reproductive failure in ART, taking up to $70 \%$ of their structure. Successful implantation requires a receptive endometrium, a functional embryo at the stage of
\end{abstract}


blastocyst, and a synchronized "dialogue" between maternal and embryonic tissues $[5,6]$. The problem of repeated implantation failure is considered to be one of the most difficult to overcome in the practice of reproductive medicine and infertility specialists.

The processes required for conception, such as trophoblast invasion and further fetus development, occur in the endometrium during certain days [7]. Due to the formation of connective tissue, as a result of prolonged inflammation in the endometrium, blood circulation is disturbed, and sensitivity to hormones decreases; thus, changes in normal functioning cause chronic endometritis [8].

Chronic endometritis (CE) is a clinicopathologic syndrome where as a result of prolonged damage to the endometrium by an infectious agent, morphofunctional changes take place, disrupting the cyclic transformation and receptor apparatus of the uterine mucosa [5]. This pathology occurrence rate varies from 3 to $73 \%$, giving rise to primary infertility in $24.8 \%$, secondary infertility in $35.6 \%$, unsuccessful IVF attempts and embryo transfers in past medical history in $30 \%$ of cases, as well as miscarriage, complicated pregnancy, and childbirth $[9,10,11]$.

Risk factors for the development of $\mathrm{CE}$ in patients of reproductive age with menstrual dysfunction are age group of women older than 30 years, the presence of urinary system diseases, history of abortion and premature birth, chronic salpingo-oophoritis and endometrial polyps, history of uterine fibroids, surgical interventions on the reproductive system organs, prolonged use of intrauterine contraceptives $[8,12,13]$.

In $95 \%$ of cases, endometritis is exogenous (primary), caused by sexually transmitted infections, or occurred as a result of intrauterine diagnostic and treatment procedures. In the other $5 \%$ of cases, endometritis is endogenous (secondary) and develops when infection from extragenital sources gets through hematogenous, lymphogenous, or descending pathways $[5,8,12]$.

$\mathrm{CE}$ has typical characteristic features such as a change in the etiological structure, drug-resistant bacterial flora growth, long periods of therapy, changes in clinical symptoms towards weakened or barely perceptible forms and atypical course of a disease. CE clinical presentation includes disruption of menstrual and reproductive functions. A persistent inflammation area existing in the small pelvis results in disruption of the menstrual cycle in $45-55 \%$ of patients, manifesting in the form of meno- and metrorrhagia, oligo- and opsomenorrhea, algodismenorrhea, and amenorrhea. $21 \%$ of patients experience chronic pain $[14,15] .80-90 \%$ of patients suffering from CE present with symptoms as intermenstrual bleeding, menorrhagia, and contact-spotting $[5,12]$.

In $60 \%$ of cases of typical miscarriages, there is a close link to CE. Endometrial stromal fibrosis takes the main part in the pathogenesis of this problem, resulting in a significant decrease in blood flow due to the reduction of the capillary bed. This, in turn, leads to inadequate secretory transformation of the endometrium and disrupts pregravid restructuring of the mucosa of the uterine body $[5,12,13]$.

The CE diagnosis is based on a comprehensive assessment of a number of clinical, morphological, and instrumental data.

A comprehensive method for the diagnosis of CE allowed to improve verification of this pathology by $64.6 \%$ compared to histological confirmation of CE only after a biopsy of the endometrial tissue [16].

Ultrasound examination of pelvic organs is a screening method for chronic endometritis. Sonographic signs of CE include the following: irregular form areas and reduced echogenicity of the endometrium; changes in the endometrium structure; identification of gas bubbles, sometimes with the typical "comet tail" acoustic effect; clear hyperechoic formations $0,1-0,2 \mathrm{~cm}$ in diameter, visualized in the basal endometrium layer and being sources of fibrosis, calcinosis; expansion of the uterine cavity up to 0,3-0,7 cm due to fluid contents. Dopplerometric studies show hemodynamic disturbances in the vessels of the uterus and the vascular basin of the pelvis and asymmetry of the myometrium vascularization $[8,12,13,17]$.

During hysteroscopy, the uneven color and hyperemia of the endometrium are observed. Morphological examination of the endometrium on the 7-10th day of the menstrual cycle is the "golden standard" for the CE diagnosis $[13,5]$. Diagnostic signs of CE detected during hysteroscopy are revealed only in $82,6 \%$ of patients, which is verified by the morphological method and immunohistochemical CD138 studies [8, 18, 19, 20, 21]. These data coincide with the results of studies accomplished by other authors, demonstrating that only $30 \%$ of female patients have the most informative CE signs, such as uneven thickness of the endometrium, polypoid growths, uneven color and hyperemia of the mucous membrane. At the same time, the sensitivity of this method is only $40 \%$ and specificity is $80 \%$

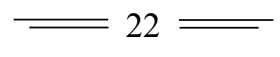


(for comparison, the corresponding morphological indexes of endometrial aspirates are 93 and $100 \%$ \% [22]. Therefore, in cases of suspected CE, hysteroscopy is an important step to exclude the entire spectrum of intrauterine pathology, but not to verify the diagnosis.

Comprehensive treatment of chronic endometritis should include antibacterial, metabolic, antioxidant, immunomodulating and physiotherapy. The therapy effectiveness criteria present as relief of clinical symptoms, restoration of the endometrium echographic picture, elimination or reduction of the infectious agent activity, restoration of the morphological structure of the tissue, as well as restoration of fertility.

Despite the recent innovations in stimulation protocol schemes, reproductive immunology, culture medium, technical equipment, and application of preimplantation genetic testing, implantation and genetic health of embryos remain the leading cause behind the effective implementation of IVF programs $[15,23,24]$.

The issues of pregravid preparation of married couples, taking into account microflora status and dysbiosis of the vagina and uterus, are being discussed [19].

The problem of relatively ineffective results in ART programs leads one to consider various aspects of increasing the frequency of implantation and childbirth.

The effectiveness of IVF programs directly correlates with the age of female patients; according to various authors, embryo implantation takes place more often in patients of a younger age [25].

During the initial implantation stages, the endometrium is invaded by trophectoderm cells; thus, cytoplasmic characteristics of invading cells play a significant role. Probable genetic abnormalities during further embryo growth might lead to a developmental arrest. Perhaps, this sequence of events leads to a high incidence of clinical pregnancy, along with a high frequency of pregnancy interruption in female patients of young age. The low rate of progressive pregnancy after embryo transfer (ET) within a group of women over 40 years old allows doctors to recommend these patients the use of donor oocytes $[25,26]$.

Among the variety of causes for failed embryo implantation, endometrial thickness remains one of the most important factors affecting pregnancy rate in ART. Good quality embryo and receptive endometrium are the main factors for achieving a successful pregnancy. That is why thin endometrium significantly reduces the pregnancy rate. Endometrium thickness of less than $7 \mathrm{~mm}$ is believed to give minimal chances for successful conception [27].

The study of American scientists regarding the effects of endometrial thickness on pregnancy rate in 897 female patients with embryo transfer in IVF programs revealed that high pregnancy rate is observed in women with an endometrial thickness of $9 \mathrm{~mm}$ or more, making it $39 \%$ of females tested, whereas in patients with an endometrial thickness of less than $9 \mathrm{~mm}$ it was $16 \%[27,28]$.

The use of technologies, such as hyperbaric oxygenation therapy (HOT), in patients preparing for IVF programs in both men and women, leads to oxygen deficiency elimination, regional hemodynamics improvement, biosynthesis activation; moreover, it has an anti-inflammatory and immunomodulating effect [28] for embryo transfer and treatment of "thin endometrium" [30, 31, 32]. The procedure can be performed not only during ovarian stimulation but also before and after embryo transfer.

On a 20-21st day of the cycle, endometrial scratching by pipelle-biopsy carried out using a special catheter, and a sample is sent for histological and immunohistochemical studies if necessary. According to modern data, there are conflicting opinions about the effectiveness of endometrial scratching. Some studies provide information that confirms an increase in implantation rate, pregnancy, and childbirth $[33,34]$. At the same time, other studies have not shown a significant increase in the positive outcome of embryo transfer programs $[30,31,32,35,36]$.

To improve the receptivity and thickness of the endometrium, in 2011, researchers proposed the use of granulocyte colony-stimulating growth factor (G-CSGF) for the first time. The mechanism of action consists of colony-stimulating factors taking part in the repeated modeling of endometrial vessels, local immune modulation, and cell pathways of adhesion [30,37].

Studies regarding the use of peripheral blood mononuclear cells show that, within the implantation site, maternal blood containing peripheral blood mononuclear cells (PBMC) surrounds the embryo. The number of maternal immune cells dramatically increases during the decidualization process. PBMCs directly interact with trophoblast and then return to the mother's bloodstream. There is a suggestion that PBMCs, along with human chorionic gonadotropin (HCG), contribute to the interaction between the embryo and the endometrium. Therefore, intrauterine administration of mononuclear cells from

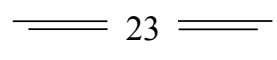


autologous blood cells suggests an increase in endometrial receptivity of female patients with repeated embryo transfer failure [21, 30, 38].

As of today, there are several studies on the use of platelet-rich plasma; the first studies were published in 2015 by Y. Chang et al. [29, 38]. With intrauterine administration of plasma, the release of biologically active substances, cytokines, and growth factors takes place. Among those growth factors are fibroblast growth factor, platelet growth factor, vascular endothelial growth factor, transforming growth factor, IGF-1, IGF-2, connective tissue growth factor, and interleukin-8. S. Zadehmodarres et al., and A. Molina et al. in their studies noted the positive impact of this technique on outcome results in female patients with thin endometrium and RIF [27, 40, 41].

The individual implantation window is a short period, corresponding to the 7-8th day after the luteinizing hormone peak, during which adhesion and invasion of the blastocyst into the endometrium becomes possible. In 2011, a group of researchers developed a transcription ERA signature, which makes it feasible to determine the susceptibility of the endometrium to embryo implantation based on an integrated algorithm for assessing the expression levels of matrix RNA-238 genes [41, 42]. In the natural cycle before ET, on the 7th day after ovulation or on the 5th day of taking progesterone, in cycles with cyclic hormonal therapy, endometrial pipelle-biopsy is performed. After receiving the results that the endometrial receptivity status corresponds to the stage of the implantation window, preparations for the ET procedure begin, performing it on the same day of the cycle with the established endometrial receptivity. In the case of detecting a non-receptive status of the endometrium, the procedure is repeated, changing the day of material sampling, sometimes repeating the study in several cycles, until a positive result is obtained. Thus, the authors proposed an individual approach to choosing the day for ET $[41,42,43]$.

Treatment of the uterine cavity with a mixture of $\mathrm{CO} 2$ and N2 gases improves blood circulation in the endometrium and increases the thickness of basal and functional endometrial layers [44, 45].

Gynecological massage is a scientifically proved therapeutic method that is widely used in gynecological practice in Russia but has not yet found proper application in preparing women for IVF [27].

Physiotherapeutic procedures are important methods for treating female reproductive system disorders, as well as acute and chronic pathologies. Modern, technologically advanced techniques of physiotherapeutic treatments include ultrasonic (US) cavitation of the uterine cavity. This method can be used in both complex treatments, in combination with drug therapy, and also as monotherapy. There are two possible ways to perform this procedure: contact (through a liquid medium) and non-contact. The finely-dispersed cavitated solution is used as a liquid medium to irrigate the tissue.

Ultrasonic irrigation methods are based on the effect of low-frequency ultrasonic vibrations (up to 50 $\mathrm{kHz}$ ) on a solution, passing through a $2 \mathrm{~mm}$ diameter hole in the working part of the waveguide. In this case, the process of cavity formation, called cavitation, takes place in the areas of rarefaction of the medium. The resulting cavity is filled with vapors of liquid and gas, soluble in the mentioned fluid. During the formation of cavitation bubbles, the medium is compressed, and the previously formed cavities burst, accompanied by sharp hydraulic impacts $[12,13,46]$.

Treatment of the uterine cavity with antiseptic solutions, cavitated by low-frequency ultrasound, is characterized by the following therapeutic effects: antibacterial, immunological, potentiating, trophic, microcirculatory, and antioxidant [8].

Antibacterial and immune therapeutic effects manifest in a direct antimicrobial action due to the disintegration of the microbial wall, the destruction of bacterial biofilms, and the activation of local immune reactions; while inactivation of viruses occurs due to their oxidation by free radicals and peroxidation compounds that briefly form in the intercellular space. The potentiating effect can be seen in increasing sensitivity of microorganisms to the action of antibiotics and antiseptics, which leads to their rapid elimination with small doses of drugs. Microcirculatory and antioxidant effects are achieved by improving local blood flow due to myometrium micro-massage, resulting in an increase in endometrium thickness during its hypoplasia (thin endometrium), prevention of scarring tissue changes, and development of adhesions [47, 48, 49, 50, 51]. In preparation for ART and treatment during pregnancy, combined use of uterine cavity irrigation with medicinal solutions, cavitated by low-frequency ultrasound, as well as mud therapy in women after termination of non-developing pregnancy, results in a significant 
decrease in the level of pro-inflammatory cytokines and normalization of the genital tract microbiocenosis and anaerobic vaginal dysbiosis $[50,51,53,54,55,56]$. The scope of possible usage for ultrasound cavitation varies; some of the cases are endometritis, myometritis, purulent wounds, postpartum ulcers, vaginitis, cervical insufficiency, preparation for intrauterine interventions. The technique shows good clinical results and may come to be a real alternative to multistage antibiotic therapy $[57,58,59]$.

Timely diagnosis and modern principles of treatment of $\mathrm{CE}$ with a personalized approach can increase the effectiveness of IVF programs and reduce the frequency of miscarriage.

Despite the high achievements in scientific and clinical practice, the search continues for various ways to increase the effectiveness of IVF programs.

\author{
Л.Р. Чалова ${ }^{1}$, В.Н. Локшин ${ }^{2}$, М.Р. Оразов ${ }^{3}$, \\ А.Н. Рыбина ${ }^{2}$, Т.В. Ким ${ }^{1}$, А.А. Кинжибаев ${ }^{1}$ \\ ${ }^{1}$ TOO Health and Science Center «M1», Нұр-Сұлтан, Қазақстан; \\ ${ }^{2}$ МКЦР «Persona», Алматы, Қазақстан; \\ ${ }^{3}$ ФГАОУ ВО «Ресей халықтар достығы университеті», Мәскеу, Ресей
}

\title{
СОЗЫЛМАЛЫ ЭНДОМЕТРИТ ДИАГНОСТИКАСЫ МЕН ЕМІНІН ЗАМАНАУИ ЭДІСТЕРІ, ПАЦИЕНТТЕРДІ КОЛДАУ БАҒДАРЛАМАЛАРЫНА ДАЙЫНДАУДА ҚОЛДАНЫЛАТЫН РЕПРОДУКТИВТІ ТЕХНОЛОГИЯЛАР (ӘДЕБИЕТКЕ ШОЛУ)
}

Аннотация. Қазіргі уақытта созылмалы эндометрит проблемасының өзектілігі тек медициналық тұрғыдан ғана емес, сонымен қатар әлеуметтік тұрғыдан да маңызға ие болып отыр, Өйткені бұл ауру көбінесе репродуктивті функцияның бұзылуына, бедеулікке, ЭКҰ-ның сәтсіздігіне, жүктілікке және жүктілік пен босануға әкеледі. Жатырдың шырышты қабатында эмбрионды сәтті бекіту үшін эндометрияның қалыңдығы кем дегенде 7 см болуы керек. Эндометриялық гипоплазия кезінде имплантация жасалуы мүмкін, бірақ тіркеме нәзік болып, мұндай жүктілік оның дамуын одан ары тоқтатуы мүмкін. Соңғы уақытта, аллергиялық реакциялардың, дисбактериоздың даму жиілігінің жоғарылауына және антибиотикалық терапия кезінде микроорганизмдердің төзімді штамдарының пайда болуына байланысты осы асқынулардың алдын алу үшін емдеудің жаңа әдістерін іздеу жүргізіліп келеді. Бірқатар талаптарды қанағаттандыратын созылмалы эндометритті емдеудегі осындай әдістердің бірі (тиімділік, қолайлылық, қолжетімділік, қауіпсіздік) - жатыр куысына ультрадыбыстық кавитация енгізу әдісі.

Түйін сөздер: ҚРТ, бедеулік, созылмалы эндометрит, эндометриялық гипоплазия, ЭКО сәтсіз әрекеттері, ультрадыбыстық кавитация.

\author{
Л.Р. Чалова ${ }^{1}$, В.Н. Локшин ${ }^{2}$, М.Р. Оразов ${ }^{3}$, \\ А.Н. Рыбина ${ }^{2}$, Т.В. Ким ${ }^{1}$, А.А. Кинжибаев ${ }^{1}$ \\ ${ }^{1}$ TOO Health and Science Center «M1», Нур-Султан, Казахстан; \\ ${ }^{2}$ МКЦР «Persona», Алматы, Казахстан; \\ ${ }^{3}$ ФГАОУ ВО «Российский университет дружбы народов», Москва, Россия
}

\section{СОВРЕМЕННЫЕ МЕТОДЫ ДИАГНОСТИКИ И ЛЕЧЕНИЯ ХРОНИЧЕСКИХ ЭНДОМЕТРИТОВ В ПОДГОТОВКЕ ПАЦИЕНТОК К ПРОГРАММАМ ВСПОМОГАТЕЛЬНЫХ РЕПРОДУКТИВНЫХ ТЕХНОЛОГИЙ (ОБЗОР ЛИТЕРАТУРЫ)}

\begin{abstract}
Аннотация. В настоящее время актуальность проблемы хронического эндометрита приобретает не только медицинское, но и социальное значение, поскольку данное заболевание часто приводит к нарушению репродуктивной функции, являясь причиной бесплодия, неудачных попыток ЭКО, невынашивания беременности, осложненного течения беременности и родов. Для успешного закрепления эмбриона в слизистой оболочке матки, толщина эндометрия должна составлять не менее 7 см. При гипоплазии эндометрии есть вероятность того, что имплантация произойдет, но прикрепление может оказаться непрочным и такая беременность может в дальнейшем прекратить свое развитие. В последнее время в связи с ростом частоты развития аллергических реакций, дисбактериоза и возникновением резистентных штаммов микроорганизмов при антибактериальной терапии ведётся поиск новых методов лечения, позволяющих
\end{abstract}

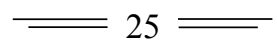


избежать этих осложнений. Одним из таких методов в терапии хронического эндометрита, удовлетворяющих ряду требований (эффективность, комфортность, доступность, безопасность), является метод ультразвуковой кавитации полости матки.

Ключевые слова: ВРТ, бесплодие, хронический эндометрит, гипоплазия эндометрия, неудачные попытки ЭКО, ультразвуковая кавитация.

\section{Information about authors:}

Chalova Leila, reproductive medicine and fertility specialist, obstetrician and gynaecologist, Director of LLP Health and Science Center "M1", Nur-Sultan, Kazakhstan, 1saat@mail.ru, https://orcid.org/0000-0003-3040-3751

Lokshin Vyacheslav, PhD, professor, Director of ICCR "PERSONA", Almaty, Kazakhstan; v_lokshin@persona-ivf.kz; https://orcid.org/0000-0002-4792-5380;

Orazov Mekan, MD, Professor at the Department of obstetrics and gynecology with course of Perinatology of the PFUR, Moscow, Russia; omekan@mail.ru. https://orcid.org/0000-0002-1767-5536;

Kim Tatyana, PhD, reproductive medicine and fertility specialist, obstetrician and gynaecologist of LLP Health and Science Center "M1", Nur-Sultan, Kazakhstan, kimtv_12@mail.ru, https://orcid.org/0000-0001-9964-9042;

Kinzhibayev Arman, clinical embryologist of LLP Health and Science Center "M1", Nur-Sultan, Kazakhstan; kinzhibay@gmail.com; https://orcid.org/0000-0002-1752-0964;

Rybina Anastassiya, reproductive medicine and fertility specialist, obstetrician and gynaecologist of ICCR "PERSONA", Almaty, Kazakhstan; oedema@mail.ru; https://orcid.org/0000-0002-9368-6683

\section{REFERENCES}

[1] World health statistics. Geneva, WHO, 2011

[2] Nazarenko T.A. Stimulation of ovarian function/T.A. Nazarenko. M.: MEDpress-inform, 2015. p. 288.

[3] Volkov N.I. Clinical picture, diagnosis and treatment of infertility in women with external genital endometriosis//Paths of development of modern gynecology: thesis. M., 1995. p. 159.

[4] Clinical practice in reproductive medicine / Edited by V.N. Lokshina, T.M. Dzhusubalieva. Almaty: MedMedia Kazakhstan, 2015. p. 464.

[5] Rudakova E.B., Mozgovoy S.I., Pilipenko M.A. et al. Chronic endometritis: from improving the diagnostic approach to optimizing treatment // Attending physician. 2008. No. 10. p. 6-10.

[6] Simon C., Martin J., Pellicer A. Paracrine regulators of implantation // Baillieres Best Pract. Res. Clin. Obstet. Gynaecol. 2000. N14. P. 815-826.

[7] Ashary N., Tiwari A., Modi D. Embryo Implantation: War in Times of Love // Endocrinology. Feb., 2018. V.159. N 2. P. 1188-1198. doi: 10.1210/en.2017-03082.

[8] Radzinsky V.E., Petrov Yu.A., Polina M.L. Chronic endometritis: contemporary aspects // Kuban Scientific Medical Bulletin. 2017. V.24. No. 5. P. 69-74.

[9] Rudakova E.B., Fedorova E.A., Sergeyeva I.V. Possibilities for improving the effectiveness of IVF and ET in patients of older reproductive age // Attending physician. 2017. No. 12. p. 11-16.

[10] Rudakova E.B., Davydov P.V., Davydov V.V. Diagnosis of intrauterine pathology in preparation for in vitro fertilization // Attending physician. 2015. No. 1. p. 83-86.

[11] Lokshin V.N., Isenova S.Sh., Rybina A.N. et al. Modern possibilities of increasing the effectiveness of art programs in women of Older reproductive age // Reproductive Medicine. 2017. No. 3. P. 67-72.

[12] Imaduddin F., Seleznyova N. A. Algorithms for the diagnosis of chronic endometritis // Young Scientist. 2016. No. 22.1. P. 5-8.

[13] Ozerskaya I.A., Ghazaryan G. Ultrasonic diagnosis of endometritis: peculiarities of blood supply of different morphological types // Bulletin of RUDN University. Series: MEDICINE. 2019. V.23. No. 2. P. 147-155.

[14] Yutskovsky A.D., Kurleeva T.Yu., Puzina O.K. Optimization of therapy for chronic pelvic pain in women with STDs // Bulletin of Dermatology and Venereology. 2005. No. 2. P.55-56.

[15] Orazov M.R., Radzinsky V.Y., Khamoshina M.B., Lokshin V.N. et al. Gonadotropin-releasing hormone agonists and antagonists: influence on neuroangiogenesis and apoptosis in eutopic endometrium in a therapy for recurrering endometriosis genitalis externa-associated pelvic pain in patients // Bulletin of National Academy of Sciences of Republic of Kazakhstan - 2018. No 376. P.19-33. https://doi.org/10.32014/2018.2518-1467.

[16] Boyarsky K.Yu., Gaidukov S.N., Palchenko N.A. A modern view of the problem of receptivity and thin endometrium in ART programs (literature review) // Reproduction Problems. 2013. No. 4. P. 51-60.

[17] Kamenetsky B.A. The use of ultrasonic scanning of the endometrium in assisted reproduction programs // Reproduction Problems - 2001. No. 2. P. 33-38.

[18] Sukhikh G.T., Shurshalina A.V. Chronic endometritis: Guidebook. M.: GEOTAR-Media. 2010. p. 64.

[19] Zazulina Ya.A. Identification and correction of controlled clinical predictors of the effectiveness of the in vitro fertilization method. Abstract of thesis Cand of medical Sciences // Samara. 2017. p. 24. 
[20] Zhang Y., Xu H., Liu Y. et al. Confirmation of chronic endometritis in repeated implantation failure and success outcome in IVF-ET after intrauterine delivery of the combined administration of antibiotic and dexamethasone // Am. J. Reprod. Immunol. Nov., 2019. V.82. N 5. e13177. doi: 10.1111/aji.13177. Epub 2019 Aug 20.

[21] Alberto E Tersoglio, Sebastian T., Dante R. Salatino et al. Regenerative therapy by endometrial mesenchymal stem cells in thin endometrium with repeated implantation failure. A novel strategy // JBRA Assisted Reproduction. 2019. doi: 10.5935/1518-0557.20190061.

[22] Glukhov E.Yu., Dicke GB, Neff E.I. Chronic endometritis and incompetent uterine scar after cesarean section. Longterm results of metroplasty // Obstetrics and Gynecology. 2019. No. 2.

[23] Radzinsky V.E., Petrov Yu.A., Kalinina E.A. et al. Pathogenetic pculirarities of macrotypes of chronic endometritis // Kazan Medical Journal. 2017. No. 1. p. 27-34.

[24] Lokshin V., Valiev R., Rybina A. et al. Poor responders - modern ideas, principles of management in ART programs. Review // Bulletin of National Academy of Sciences of the Republic of Kazakhstan. 2019. V.2. N 378. P. 177-188.

[25] Yakovenko S.A., Khryapenkova T.G., Kiriyenko K.V. et al. A comparative analysis of the efficiency of embryo transfer in the induction cycle of superovulation and cryocycle in patients of different age groups. doi: 10.17116/repro201622150-54.

[26] Polovneva M.I., Korneeva I.E., Burmenskaya O.V. Modern exposure methods aimed at increasing receptivity of the endometrium in patients with unsuccessful attempts of in vitro fertilization (literature review) // Gynecology. 2018. No. 3. p. 66-70.

[27] Schneiderman MG. Kalinina EA, Smolnikova V.Yu. et al. The problem of thin endometrium: the possibilities of combined non-hormonal treatment in preparation for the in vitro fertilization procedure // Gynecology. 2014. No. 3. p. 67-71.

[28] Zhang X., Chen C., Confino E et al. Increased endometrial thickness is associated with improved treatment outcome for selected patients undergoing in vitro fertilization-embryo transfer// Fertility and Sterility. 2005. V.83. P. 336-340.

[29] Skoropatskaya O.A., Remneva O.V., Yavorskaya S.A. et al. Pre-conception preparation of patients with chronic endometritis: assessment of the effectiveness of phyto- and physiotherapy // Issues of balneology, physiotherapy and exercise therapy. 2018. No. 4. p. 41-47.

[30] Polovneva M.I., Korneyeva I.E., Burmenskaya O.V. Modern methods of exposure aimed at increasing the receptivity of the endometrium in patients with unsuccessful in vitro fertilization attempts (literature review) // Gynecology. 2018. No. 3. P. 66-70.

[31] Nastri C., Lensen S., Gibreel A. et al. Endometrial injury in women undergoing assisted reproductive techniques. Cochrane Database Syst. Rev. 2015; 3: CD009517.

[32] Krasnopolskaya K.V., Nazarenko T.A., Fedorov A.A. et al. Clinical outcomes of IVF programs with donor oocytes using endometrial scratching technology in patients with extreme moderate endometrial development delay // Med. alphabet. 2017. No. 3. P. 46-50.

[33] Mahran A., Ibrahim M., Bahaa H. The effect of endometrial injury on first cycle IVF/ICSI outcome: A randomized controlled trial // Int. J. Reprod. Biomed (Yazd). 2016. V.14. N3. P. 193-198.

[34] Potdar N., Gelbaya T., Nardo L. Endometrial injury to overcome recurrent embryo implantation failure: a systematic review and meta-analysis // Reprod. Biomed Online. 2012. V.25. N6. P. 561-571.

[35] Yeung T., Chai J., Li R. et al. The effect of endometrial injury on ongoing pregnancy rate in unselected subfertile women undergoing in vitro fertilization: a randomized controlled trial // Human Reprod. 2014. V.29. N11. P. 2474-2481.

[36] Liu W., Tal R., Chao H. et al. Effect of local endometrial injury in proliferative vs. luteal phase on IVF outcomes in unselected subfertile women undergoing in vitro fertilization // Reprod. Biol. Endocrinol. 2017. V.15. N 1. 75 p.

[37] Gleicher N., Vidali A., Barad D. Successful treatment of unresponsive thin endometrium // Fertility and Sterility. 2011. V.95. P. 2123.e13-2123.e17.

[38] Fujiwara H. Do circulating blood cells contribute to maternal tissue remodeling and embryo-maternal cross talk around the implantation period? // Mol. Hum. Reprod. 2009. N15. P. 335-343.

[39] Chang Y., Li J., Chen Y. et al. Autologous platelet-rich plasma promotes endometrial growth and improves pregnancy outcome during in vitro fertilization // Int. J. Clin. Exp. Med. 2015. V.8. N 1. P. 1286-1290.

[40] Hashimoto T., Koizumi M., Doshida M. et al. Efficacy of the endometrial receptivity array for repeated implantation failure in Japan: A retrospective, two-centers study // Reprod. Med. Biol. 2017. N 16. P. 290-296.

[41] Zhang X., Chen C., Confino E. et al. Increased endometrial thickness is associated with improved treatment outcome for selected patients undergoing in vitro fertilization-embryo transfer// Fertility and Sterility. 2005. N.83. P. 336-340.

[42] Tandulwadkar S., Naralkar M., Surana A. et al. Autologous Intrauterine Platelet-Rich Plasma Instillation for Suboptimal Endometrium in Frozen Embryo Transfer Cycles: a Pilot Study // J. Hum. Reprod. Sci. 2017. V.10. N 3. P. 208-212.

[43] Díaz-Gimeno P., Horcajadas J., Martínez-Conejero J. et al. A genomic diagnostic tool for human endometrial receptivity based on the transcriptomic signature // Fertility and Sterility. 2011. N.95. P.50-60.

[44] Schneiderman M.G., Apolikhina IA, Kalinina EA et al. New on embryo implantation in the endometrium // Akush. and gynecol. 2013. No. 11. p. 75-78.

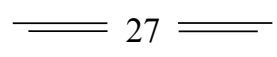


[45] Schneiderman MG, Kalinina EA, Dolgushina N.V. et al. A new method for increasing the thickness of the "thin endometrium" in preparation for the embryo transfer procedure // Theses of the Anniversary All-Russian. Congress "Outpatient care - at the epicenter of women's health." Sat abstracts. M. 2014. p. 349-352.

[46] Franasiak J.M. Chronic endometritis is associated with an altered microbiome, but what about treatment and clinical outcomes? // Fertil Steril. 2019. V. 112(4). - P. 649-650.

[47] Glukhov E.Yu., Bogdanova A.M., Kozyreva E.N. The use of low-frequency ultrasound in the treatment of patients with chronic endometritis suffering from various forms of infertility // Russian Bulletin of Obstetrician-Gyneacologist - 2015. T.15. No. 1. P. 32-37.

[48] Melkozerova O.A., Bashmakova N.V., Patsyuk O.V. The energy of low-frequency ultrasound in the treatment and prevention of chronic endometritis as a pathogenetic factor in an undeveloped pregnancy // Russian Bulletin of ObstetricianGynecologist - 2012. V. 12. No. 5. P. 31-35.

[49] Zdanovsky V.M., Buravchenko N.V. The results of using assisted reproductive technologies in infertile patients with endometrial pathology // Russian Bulletin of Obstetrician-Gynecologist. 2010. No. 4. P. 39-42.

[50] Melkozerova O.A., Gluchov Y., Bashmakova N. The Efficiency of Intrauterine Irrigation of the Cavitated Drug Solutes in Patients with Endometrial Receptivity Disorders // Journal of Gynecology and Obstetrics. 2018. V.6. N 4. P. 98-107/

[51] Podolyan O.F., Tsaregorodtseva M.V. The use of ultrasonic cavitation of medicinal solutions in the treatment of mild forms of postpartum endometritis. GBUZ MO "Moscow Regional Perinatal Center", Balashikha, FSBI SSC FMBA named after A.I. Burnazyan FMBA of Russia, Moscow. Abstracts of reports of the XVI All-Russian Scientific Forum "Mother and Child". Moscow. 2015. P. 168.

[52] Omarpashaeva M.I., Dicke G.B., Abusueva Z.A. et al. Restoration of endometrial receptivity in women after a failed miscarriage // Obstetrics and Gynecology. 2019. No. 1. P. 109-116.

[53] Omarpashaeva M.I., Abusueva Z.A., Khashaeva T.Kh-M. et al. Combined effect of low-frequency ultrasonic cavitation and pelotherapy on the content of cytokines and the state of genital tract microbiota after interruption of a non-developing pregnancy // Problems of reproduction. 2018. V.24. No. 4. P. 102-107.

[54] Glukhov E.Yu., Dicke G.B. Application and clinical effects of low-frequency ultrasonic cavitation in obstetrics and gynecology // Obstetrics and Gynecology. 2016. No. 1. P.103-110.

[55] Khayutin L.V., Plotko E.E., Voroshilina E.S. Anaerobic vaginal dysbiosis during pregnancy: peculiarities of the course and correctability // Ural Medical Journal. 2016. No. 2. p. 55-60.

[56] Totchiev G.F., Gulmukhammedova D.Ch. Experience in conducting comprehensive rehabilitation after a nondeveloping pregnancy // Zhinochiy Likar. 2012. No. 1. P. 14-19.

[57] Oboskalova T.A., Glukhov E.Yu., Plotko E.E. et al. Ultrasonic demedicalization? // StatusPraesens. 2012. No. 3. p. $65-69$.

[58] Chalova L.R. Efficiency of Conditioning of Patients with Overweight for Programs of Assisted Reproductive Technologies // Reproductive Medicine - 2017. No. 3. P. 28-31.

[59] Lokshin V., Valiev R., Rybina A., Zaichenko K. "Poor responders" - modern ideas, principles of management in ART programs. Review // Bulletin of National Academy of Sciences of Republic of Kazakhstan - 2019. No 378. P.177-188. https://doi.org/10.32014/2019.2518-1467.54 


\title{
Publication Ethics and Publication Malpractice in the journals of the National Academy of Sciences of the Republic of Kazakhstan
}

For information on Ethics in publishing and Ethical guidelines for journal publication see http://www.elsevier.com/publishingethics and http://www.elsevier.com/journal-authors/ethics.

Submission of an article to the National Academy of Sciences of the Republic of Kazakhstan implies that the work described has not been published previously (except in the form of an abstract or as part of a published lecture or academic thesis or as an electronic preprint, see http://www.elsevier.com/postingpolicy), that it is not under consideration for publication elsewhere, that its publication is approved by all authors and tacitly or explicitly by the responsible authorities where the work was carried out, and that, if accepted, it will not be published elsewhere in the same form, in English or in any other language, including electronically without the written consent of the copyright-holder. In particular, translations into English of papers already published in another language are not accepted.

No other forms of scientific misconduct are allowed, such as plagiarism, falsification, fraudulent data, incorrect interpretation of other works, incorrect citations, etc. The National Academy of Sciences of the Republic of Kazakhstan follows the Code of Conduct of the Committee on Publication Ethics (COPE), and follows the COPE Flowcharts for Resolving Cases of Suspected Misconduct (http://publicationethics.org/files/u2/New_Code.pdf). To verify originality, your article may be checked by the originality detection service Cross Check http://www.elsevier.com/editors/plagdetect.

The authors are obliged to participate in peer review process and be ready to provide corrections, clarifications, retractions and apologies when needed. All authors of a paper should have significantly contributed to the research.

The reviewers should provide objective judgments and should point out relevant published works which are not yet cited. Reviewed articles should be treated confidentially. The reviewers will be chosen in such a way that there is no conflict of interests with respect to the research, the authors and/or the research funders.

The editors have complete responsibility and authority to reject or accept a paper, and they will only accept a paper when reasonably certain. They will preserve anonymity of reviewers and promote publication of corrections, clarifications, retractions and apologies when needed. The acceptance of a paper automatically implies the copyright transfer to the National Academy of sciences of the Republic of Kazakhstan.

The Editorial Board of the National Academy of sciences of the Republic of Kazakhstan will monitor and safeguard publishing ethics.

Правила оформления статьи для публикации в журнале смотреть на сайте:

www:nauka-nanrk.kz

\author{
ISSN 2518-1483 (Online), ISSN 2224-5227 (Print)
}

http://reports-science.kz/index.php/en/archive

Редакторы: М. С. Ахметова, Г. Б. Халидуллаева, Д. С. Аленов

Верстка на компьютере А.М. Кульгинбаевой

Подписано в печать 07.04.2020.

Формат 60x881/8. Бумага офсетная. Печать - ризограф.

11 п.л. Тираж 500. Заказ 2. 